\title{
THE IMPORTANCE OF CONSULTING IN CONTEMPORARY BUSINESS MANAGEMENT
}

\author{
Svetlana Vukotić, ${ }^{1}$ Jugoslav Aničić, ${ }^{2}$ Radovan Vukotić ${ }^{3}$ \\ ${ }^{1,2}$ Faculty of Entrepreneurial Business, "Union - Nikola Tesla University“, Belgrade, Serbia \\ ${ }^{3}$ TeleTrader, Belgrade, Serbia \\ cecavukotic@gmail.com, ajugoslav@yahoo.com
}

\section{Professional Paper \\ doi:10.5937/jouproman5-14307}

\begin{abstract}
Modern business is characterized by risk and uncertainty, and such an environment is reflected in the decisions taken by managers. On the other hand, management consulting is one of the most important management techniques developed over the last fifty years. The secondary effect of this invention is the rapid development of new frameworks, tools, and techniques improving the operations in a number of companies. Exposure of consulting organizations to varying combinations of business circumstances and experiences of different companies have allowed for the accumulation of valuable knowledge and business experience. From this coupling, or interaction of knowledge and experience of consulting companies, on the one hand and the needs of management companies to recognize their role and hire consultants, on the other hand, developed the importance of financial consulting and auditing. Rational management processes cannot be imagined without reliable information provided by the audit, especially as the strategic management includes the control phase. The importance and relationship between consulting and management in companies that do business according to modern principles is a central topic of consideration in this paper.
\end{abstract}

Key words: consulting, business management, management, company

\section{Introduction}

Consulting is a process used to assess risk, achieve consensus, or conduct arbitration. External management consulting experts advise company owners in order to improve their understanding of their role and mission and in order to increase the ability of successful and relevant management process implementation. Consulting involves a number of different forms. In addition to organizational consulting, there is also functional consulting in the areas of human resources, finance, marketing, sales, and increasing productivity. This consultancy covers a wide spectrum-from solving concrete problems encountered by organizations adopting or placing of a modern system of functioning of some of the above areas.

Depending on the company's investment opportunities and environmental benefits for investment, consulting includes various activities that build on each other. Offers of consulting houses depend on the need, i.e. demand for market consultancy. At the same time, the offer is conditional on human potential of the consulting house. The most important thing is the experience and expertise of the consultants, which allows them to meet the requirements of clients. This is especially important considering the rule that is five times more expensive to attract a new customer than to retain an existing one, or, what is even more pronounced than this, when it comes to brand value - it takes 20 years to build a reputation and five minutes to ruin it (Vukotić et al., 2015). 
Financial consulting is one of forms of consulting. Today, financial consulting is an important form of business promotion for the domestic and international financial and commodities markets, services and information.

With the rapid economic development, there is a growing demand in the field of financial services. Financial services consulting has created opportunities for: shortening the time required in the preparation or implementation of specific activities; providing new knowledge and know-how for which there is an objective need; introduction of new ideas and approaches in present practice; obtaining third-party, or impartial assessment and suggestions for a particular financial activity and the like.

The paper is structured around four thematic areas. The first of these refers to the entity performing the very essence, the place and role of consulting in modern business. Continuing our consideration, the paper focuses on the advantage of using consulting in making business decisions. Professional knowledge which consultants provide, in addition to being expert or professional they are impartial or objective. The next segment of the analysis is the Boston Consulting Group BCG matrix of application of consulting services to businesses. Lastly, we consider the domain's use of consulting in advanced countries and in Serbia. The aim of the study was to demonstrate that contemporary business management requires new forms of additions and transfers of knowledge that are increasingly insisting on consultation engagements was on a freelance basis or specialized consulting houses. Today's business trends are less than in past tense turn to foster and grow much of their own experts who will bring the company a competitive advantage, which indicates that the importance of consulting further improve and grow.

\section{Place and role of consulting in modern business}

Consulting is knowledge, additional value and program support for products and solutions that increase the value of the resources and assets of the client. Consulting companies provide consulting services or give more precise advice, suggestions and expert opinions in the area you have just determined and for which they have the experts. The term consulting services by default, special and comprehensive approach to solving business problems of clients. As a rule, these issues are complex and complicated character, and for finding the best solutions for the client, it is necessary to do a detailed case study and analysis of the causes that have led to the same, so in accordance with the findings, experience and real opportunities to find the best outcome.

Proper use of expertise of consultants in order to amend the corpus of knowledge that exists within the company has become a method of improving managerial effectiveness and competitive strength. Consulting can be vividly interpreted and as a guide for organizations in a particular area do not have enough knowledge or human features. Today's conditions imposed by the necessity of timely response, because it is most important to react in time. Any delay gives rise to more problems, so consulting helps organizations don't wander in looking for solutions. 
Some of the fundamental features of consulting by Kubr $(1976,7)$ are as follows:

First, consulting (advisory) is an independent service. This independence is limited by consultants enter into a very complex relationship with their client organisations and people who work in them. Basically, the consultant is added to an existing team organization requesting assistance, where his property updates at the same time, and its main role. The consultant has no direct authority to decide about changes and apply them-but this must not be considered as defects.

He needs to perfect the skills of deep consideration change without giving up their independence. Therefore, first, provides the highest degree of customer involvement in the work, so that the final success is shared success.

Secondly, consulting is essentially advisory services, meaning that you don't hire consultants to manage organizations or to make delicate decisions for managers who need this service. They are consultants (advisers) and their responsibility regarding the quality and validity of the advice that they give. It's not just about giving the right advice, but also about giving advice at the right time and in the right way-these are basic skills consultants.

The client in turn has to be very active in the process of receiving tips that originate from a consultants, trust them, and adopted as its application in your organization, because, ultimately, they bear full responsibility for the consequences of which continue to occur. Open style of governance would advocate consulting and consulting as a normal form of business conduct, and not as a sign of ignorance or weakness (Young, 1992, 146).

Third, consulting is a service that provides professional knowledge and skills which are essential for effectively addressing the problem of management (administration). What is special about consultants is that over the years through a number of organizations and learn how to use their collected experience from previous assignments in new conditions. In addition to this, professional consultants are constantly improving the methods and management techniques, including those used in universities and research institutions; transfer this experience to clients and assisting them in the implementation. They work as a link between theory and practice in management. However, by default, and managers must also possess certain types of skills, particularly in the implementation of new ideas.

Fourth, consulting is not a service that provides an easy and simple solution too difficult managerial problem. Consulting is hard, systematic and disciplined work based on analysis of solid facts and researches all possible solutions. Strong management commitment to solving problems of organization and cooperation between client and consultant alike are crucial for the quality of advice is received, as well as to the end result.

Mostconsulting services applies to: Communications Management, Business plan, Feasibility study, Investment study, Cost-benefit analysis, Marketing plan, Management plan, Study of property management, Restructuring plan, Business Process Reengineering etc. 
Management consulting has its roots in free market economies, where independent business companies used consultants in many different ways, and it quite freely and according to their needs. Consulting to the developing countries of Europe decades ago and they are active consulting organizations that differ according to the model of financing, structure and process consulting (Mihailović, 2012).

\section{Advantages of using consulting in making business decisions}

Consulting can be defined as a professional support of the company's managers in analysing and solving practical problems. It enables the transfer of successful management system from one company to another or from one organization to another. The changes are the main reason for consulting. Consulting services is recommending appropriate measures, as well as assistance in pursuing these recommendations, which is the result of research, identifying and analysing problems in a particular company.

There are different methods for consulting services, depending on the company, as well as the size of the problem (Pejanović et al., 2007). These activities range from research and the provision of managerial and business information, through downloading the client, task of conveying systems and methodologies through demonstration activities and instruction client that performs on a sophisticated methodology. Business consulting services include diagnosing client state management, presenting alternatives with recommendations, observation processes in the organization and feedback, exchange of opinions, moral support and advice, and more.

From the above follows that consulting is in a lot of directions: directly or indirectly with an executive, colleagues or subordinates. Analysis of facts enables consultants to see what are the changes necessary in company, whether they can be implemented, as well as what alternative is most effective in practice (Mihailović et al., 2006). It should always be clear ultimate goal consulting, or what it can achieve and whether it is feasible.

In addition to the so-called internal (indirect and direct) reference exists and consulting based on the search for external assistance. The main reasons for the engagement of external advisors are: the need for additional expertise (due to lack of time), the need for objectivity (unbiased advice) and the need for additional expertise (deeper knowledge and experience). Less tangible reasons for engagement of external independent consultants are (Mihailović et al., 2006):

- elimination of doubt or question that you are taking or will take proper actions;

- to expand ownership;

- to represent resonators that assess the quality of the internal decisions;

- to be reservoirs of information in terms of reviewing the overall picture, i.e. position in relation to the environment and possible comparisons with competitors

- are catalysts of change in order to be motivated to look into what was previously ignored (because of carelessness, negligence or lack of time or expertise). 
Mihailović and associates (2010b, 81) emphasized that the need for measuring the performance of the consultancy impact led to a shift in paradigm consulting. Consulting based on activities was replaced by the consulting company based on the results. Consulting interventions are associated with specific business needs of companies, consulting as a measured variable that has a significant impact on performance. One of the earliest methods to estimate the contribution of the consultancy's cost benefit analysis, which is based on the relative benefits (from consultancy interventions) and costs (Philips, 2000, 203). However, besides these tangible, there are some standards that cannot be converted into monetary values. In some consulting interventions, development team, filled with work, communication in the company and the satisfaction of users is more important than monetary standards.

Also, depending on the size of companies use different types of consulting services at a different scale. For example, small and micro enterprises use the services some management consulting. These services are mostly more general character. With the growth of the company there is an increase in the complexity of services and consulting (Dukić et al., 2013). In developed economic systems, management consulting plays an important role in the process of professionalization leaderships and the introduction of structural system of management, and management consultants are often engaged as business sparring partners for entrepreneurs or small business owners. From a consultant, in addition to the extensive knowledge, expected maturity, contiguous approach, prediction and empathy, more than large administrative procedures (Dukić, Milivojević, 2011).

Consulting is a very sensitive industry in terms of moral criteria. In fact, clients when they want to engage a consultant do that for some reason they can't do for themselves in their own firms. They were somewhat in a state of dependence and vulnerability. Client in the consulting process is on a "field" that is unknown, and that a consultant can come into possession of a very confidential data and customer information (Dukić, Vujić, 2011, 161).

It is often found in the literature about management consulting asks why we witnessed a demand for management consulting company in the United States, rather than in Japan. Part of the answer lies in the fact that the Japanese and the Americans at different stages of the cycle of development of managerial skills. More significantly, Japanese tradition much greater confidence based on long-term predictability and protection of knowledge that the party hard to accept in large firms. Impact of disruptive of external consultants in the management processes of one company in Japan for now is greater than the benefit of their expertise, encouragement and objectivity. That is, human asset specificity is high, which causes the internal problems are resolved in an internal way, of the firms (Cvijanović, Mihailović, 2010, 213).

Business consulting is a specific activity of helping managers. According to Đuričin (1999) in the practice of consulting the developed market economies has developed three forms of these activities: a model of buying expertise, model, doctorpatient and model of environmental consulting. 
The literature also highlights the division on three types of consulting services: management consulting/strategic consulting or management strategies, economic consulting and consulting information technology (Farber, 2012). Some authors extend the list of types of consulting services (Kamat, 2012). When the information technology in question then consulting services can be considered from two aspects. Thanks to information technology can be greater engagement of consultants, because they can work at a certain distance or from home - any type of business that is at stake. On the other hand, it is easier to recruit IT specialists whose expertise in the IT domain. In addition to the IT/technology consulting services, there is an operational consulting, Human Resource (HR) consulting (which has become very important in recent years), marketing and sales consulting, consulting real estate etc. For example, Torrington and associates (2004) point out that the increasingly frequent engagement of external consultants who are taking over activities in the area of human resources.

\section{BCG matrix of application consulting services in enterprises}

Of the management company are required to identify the different sources of growth and development from the standpoint of the entire portfolio of business enterprises, hence called the need for concepts that help evaluating different jobs, both in the framework of a specific portfolio of business, as well as in relation to business competitors. One of the first attempts of these variables is the study of the Boston Consulting Group (Boston Consulting Group BCG). The concept of portfolio provides adequate analytical basis for balancing the overall business from the viewpoint of different requirements (Bešić et al., 2010). They allow increasing the use of resources and assets in relation to their costs as well as optimization of the effects of the use of resources and assets for the wider community.

BCG has developed a matrix of growth and market share. Market growth rate is higher than $10 \%$ is considered high. Eight laps are the eight business units in one hypothesized company. The location of each business unit shows the rate of growth of the market and its relative share of the market. In the basic model portfolios can have four different positions in the four quadrants of the matrix that are colourfully named: stars, question marks, cash cows and dogs.

A question mark. High growth in the market and a relatively small share of the market. Most companies starting business in this segment, because there is already a market leader. To start you need a lot of capital to get the leader on the market. The company is in a dilemma, whether to continue to finance this growth market. For example, the company began three jobs in high-growth markets and low relative market share. It's much better to choose only one job, possibly two, but not all three. There is a possibility that the company too far with investment.

The stars. When work from a segment of the survey put the segment star, it becomes successful. Star is a leader in the fast-growing market. High growth markets and high market share are the characteristics of these positions. The company must invest a lot of money to be retained in this market segment and must ask for their future and deal with the more intense to deal with future projections. 
Cash cows. When annual growth rate drops below $10 \%$ of the star becomes a cash cow, symbolically. In this market segment the company earns a lot of money. Given that the company is still the market leader, turns the fruits of the economy of volume and higher profit rates. Cash flow from this segment is used to pay off loans, funded by new jobs ... However, in this segment the company must take into account the jobs Fund that would come in the dog.

Field dog. Company in this segment has jobs with low divided on slow-growing market. This segment typically generates little profit or losses.

Managing product portfolio provides a balance between creation and the use of profits. Apart from indicating the most rational directions of investing, basic portfolio matrix can provide answers on many strategic issues related to the assessment of a company's future strategy. Thus the role of consulting is a definite.

In the meantime, this model multiple modified and developed a whole range of different models for different aspects of strategic management of (Todorović et al., 1998, 221). In fact, many world-renowned consultancy houses have developed new models, which are, basically, are based on the BCG model. Some of the models were created, and as a critique of the $\mathrm{BCG}$ model. It is portfolio matrix attractiveness/business strength developed by consultancy firm McKinsey. Since it is practically applied in the company General Electric is often referred to as McKinsey/GE matrix or portfolio model (Ristić and associates, 2008, 308). Famous are also the Shell matrix, which refers to the routing policy, then a portfolio life cycle matrix (ADL Matrix) and others.

\section{Consulting services in developed countries and Serbia}

In a competitive environment, to survive, companies must constantly change and evolve. Survival and development involve the investment of effort in and organized repeated affirmation of competitive advantages of the company and their position in the market. Prokopović and Nikolić (2012, 572) note: "in some countries (France, Germany, Ireland, Singapore, United Kingdom, etc.) small and medium-sized enterprises can apply for grants or subsidies for the use of consultants for specific purposes. "For obtaining grants, a potential customer must contact the Agency for development of small enterprises and to comply with certain rules. The procedure can be provided free assistance or would accept help, to define the most appropriate forms of consulting services, be one of the conditions for obtaining grants. Typically, grants are given at a rate of up to $50 \%$ of the price of the project, provided that there is no upper limit, but rules can define and maximum daily fee to pay consultants, as well as other conditions."

To get there, and big name brand and world class in the developed markets of Europe, they hire the famous consultancy in help, singling out for that considerable resources. This way inevitably had to move and the Serbian economy, because that is the only way that leads to an economy of the European Union, and that means survival, stabilization, and development (Mihailović et al., 2010a).

Unlike the highly-developed countries in Serbia and other countries in transition consulting services are characterized by appropriate specifics that reflect the degree of and directions of economic development. 
Consulting the website adjusts to individual stages of transition. Follow the entire process of privatization consulting local businesses, starting with the preparation for privatisation, through assistance in privatization, to show capital privatised enterprises.

It's interesting research carried out on the basis of the EBRD project in
240 small businesses in Serbia which is realized in the period 2013-2016 years ago. On the basis of these indicators can be seen on the chart number 1 . It is the most consulting services in management of quality, followed by marketing, strategy, IT, etc.

Chart 1. Projects by type of consulting services

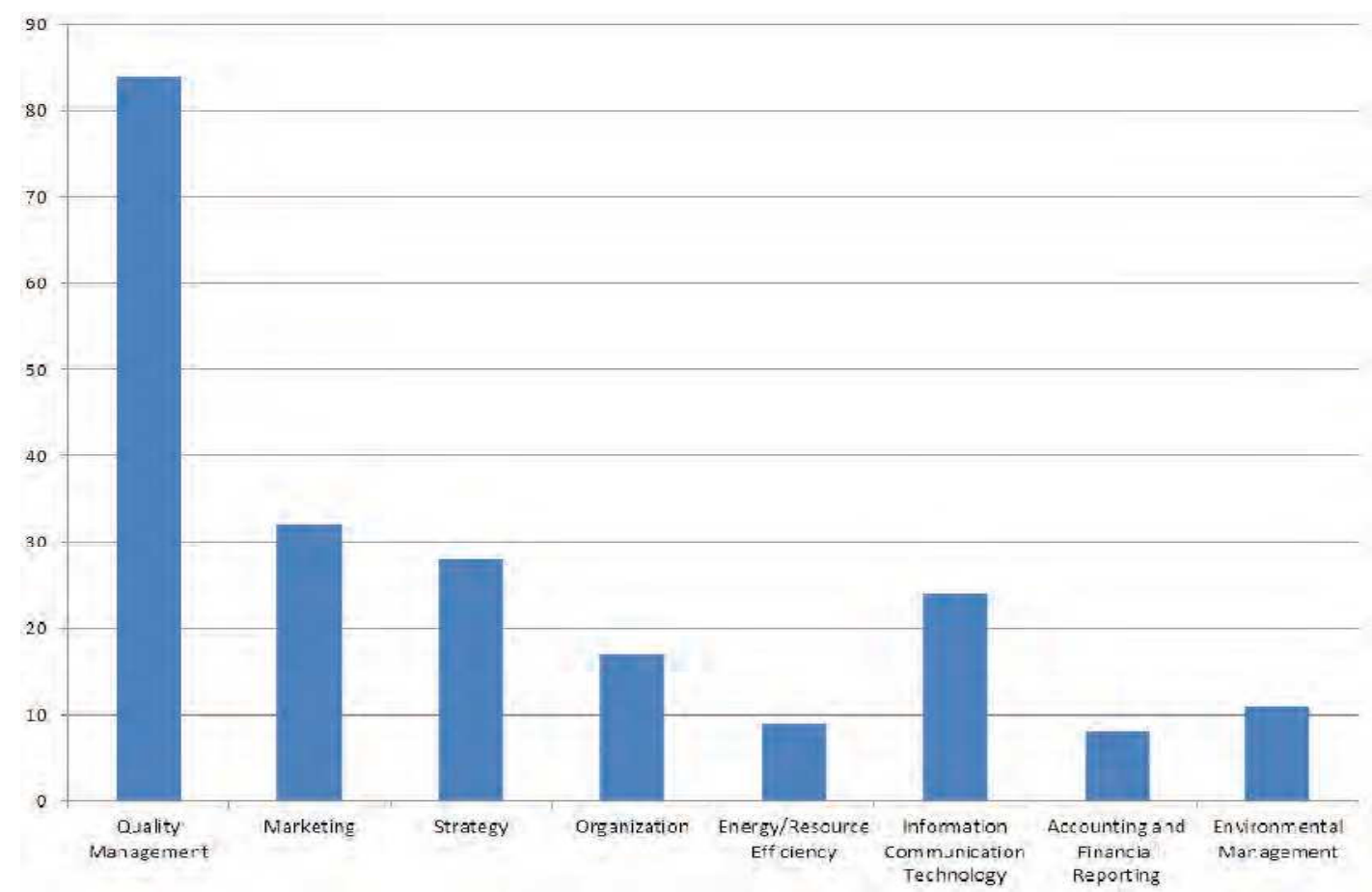

Source: Edition: Business Info Group, (2017), available on: big.co.rs/upload/Edition/Download/.../Saveti_za_mala_preduzeca_Uspesne_price.pdf

According to Prokopović and Nikolić (2012) in the future we should expect strengthening of special services: consulting and assistance in connection with the financial restructuring; provision of advice to all companies as well as governmental organizations of privatization; consulting on the corporate structure of the companies and banks; evaluating the value of a company's capital and liquidity; consultation on possible forms of integration and the joint business with companies from developed market economies and the like. 


\section{Conclusion}

Companies often hire consultants for their external or objective perspective and expert opinion, hoping to improve business performance consulting interventions. In the course of consulting project consultant and client implemented a series of activities that are required for planning and achieving the desired change. These activities are referred to as process consulting. The process of consulting can be defined using a simple model that includes five phases. The model includes the following stages: the beginning-diagnosisplanning-implementation-completion.

Consulting company can hardly continue his successful business without continuous improvement that is realized by means of the information obtained by analyzing user requirements and their positive feedback. Surprising, however, that about this show isn't much written. In part this is a consequence of a small number of interested people for this topic-and on it can be seen as the inability of a large number of managers to recognize the use of the services of consultants. The second part, it can be a consequence of the consulting firm very secretive and discreet, and therefore their activities difficult to analyse and explain.

The process of globalization of the financial flow is strongly affected by the changing sector of professional services. In modern terms, today the establishment of capital markets, is increasingly developing numerous services in the areas of financial consulting and operation of the stock market (brokers and dealers), as well as other specific services. To reduce the uncertainty of potential insolvency and insolvency that occur in business with partners that are not solid, developed a socially institutionalized system of complete, accurate and timely monitoring of business success of enterprises. This will provide information about the payment ability and economic strength of economic entities involved in commercial activities, that information is the best present to the solvency of all subjects and must absolutely be available to all interested parties.

Today, in modern conditions of operation, there are no universal or standard criteria for selection of a consultant, because each client can define their own criteria, which reflect the company's expectations and experience with using consulting services. Financial consulting can bring good results, especially if they are competent consultants for the provision of services to clients, and clients are entitled to the use of consultants. Consulting activity represents one side of a suitable form, transfer of know-how, or the necessary expertise and experience, for others it is a possibility for faster development and avoiding the unnecessary phase of wandering and possible failures. 


\section{Refrences}

[1] Bešić, C., Nikolić, M., Damnjanović, A. (2010), Strategijski menadžment, Univerzitet u Kragujevcu, Tehnički fakultet u Čačku, Čačak.

[2] Cvijanović, D., Mihailović, B. (2010), Menadžment $i$ marketing uslužnog sektora, Institut za ekonomiku poljoprivrede, Beograd.

[3] Dukić, D., Majstorović, A., Aničić, J. (2013), Obim i vrste menadžment konsalting usluga za MSP u Vojvodini, Industrija, 41 (3), 147-165.

[4] Dukić, D., Milivojević, T. (2011), Model menadžment konsaltinga za preduzetnike i vlasnike malih preduzeća, Industrija, 39 (2), 336-355.

[5] Dukić, D., Vujić, V. (2011), Konsalting u domenu preduzetništva i malog biznisa, EDASOL, Banja Luka, 23. 9. 2011., Zbornik, 157-167.

[6] Đuričin, D. (1999), Kako izbeći tranzicionu kratkovidost?, Ekonomika preduzeća, Beograd, 47(5-6), 198-204.

[7] Edition: Business Info Group, (2017), available

on: big.co.rs/upload/Edition/Download/.../Saveti_z a_mala_preduzeca_Uspesne_price.pdf

[8] Farber, J. (2012), 6 basic things you MUST know if you're interested in ...https://tuftseconsociety.wordpress.com/.../6basic, posted on site 02. 02. 2012.

[9] Kamat, S. (2012), www.mbacrystalball.com/.../managementconsult Management Consulting 101: Types of consulting, Published at June 24. 2012.

[10] Kubr, M. (1976), Management consulting - A guide to the profession, International Labour Office, Geneva.

[11] Mihailović, B. (2012), Analiza razvoja konsalting usluga u Evropi, Teme, 36 (1), 137151.

[12] Mihailović, B., Cvijanović, D., Gligić, P. (2010a), "The Role of Financial Consulting in modern business", Zbornik radova sa II Međunarodne naučno-stručne konferencije, 15 - 16. juna 2010. godine, Stavroplj - Ruska
Federacija. Stavropoljski državni poljoprivredni Univerzitet, Stavropolj - Ruska Federacija; Slovački agrarni univerzitet, Nitra Slovačka i Institut za ekonomiku poljoprivrede, Beograd - Srbija, 19-30.

[13] Mihailović, B., Hamović, V., Subić, J. (2006), Konsultantske usluge u funkciji poboljšanja konkurentnosti preduzeća u Srbiji, Ekonomske teme, Niš, 44(3), 33-49.

[14] Mihailović, B., Simonović, Z., Paraušić, V. (2010b), Metod vrednovanja konsultantskog rada, Ekonomika, godina LVI, IV-VI, broj 2, 80-93.

[15] Pejanović, R., Tica, N., Timotijević, M. (2007), Uloga i značaj konsaltinga u agrobiznisu, Savremena poljoprivreda, Novi Sad, 56(1), 165-170.

[16] Philips, J. (2000), The consultant's scorecard: tracking results and bottom-line impact of consulting projects, McGraw-Hill Companies, Inc.

[17] Prokopović, Ž, Nikolić, M. (2012), Menadžment i finansijski konsalting danas, Međunarodna naučna konferencija Menadžment 2012, 20-21. april 2012 Mladenovac, Zbornik, 568-573.

[18] Ristić, D. i saradnici (2008), Strategijski menadžment, CEKOM Books, Novi Sad.

[19] Todorović, J, Đuričin, D., Janošević, S. (1998), Strategijski menadžment, II izdanje, IZIT, Beograd.

[20] Torrington, D., Hall, L., Taylor, S. (2004), Menadžment ljudskih resursa, Data status, Beograd.

[21] Vukotić, S., Aničić, J., Zakić, N., Petrović, Ž. (2015), The Role of Marketing and Brand in Banking, Journal of Process Management - New Technologies International, 3(4), 76-83.

[22] Young, A. (1992), Priručnik za menadžere, IQ Media\&Hat, Beograd. 